\title{
PENYELIDIKAN KARAKTERISTIK LAPISAN DIAMOND FILM PAHAT KARBIDA TERHADAP PEMBEBANAN MEKANIK PADA PEMBUBUTAN KERING
}

\author{
Fransnazoan Sitorus ${ }^{1}$, Armansyah Ginting ${ }^{2}$, Basuki Wirjosentono ${ }^{3}$ \\ Dosen Politeknik Aceh Selatan ${ }^{l}$ \\ E-mail: frans.nazoanstr@yahoo.com \\ Dosen Dept. Teknik Mesin Fakultas Teknik, Universitas Sumatera Utara ${ }^{2}$ \\ Jl. Almamater, Kampus USU Medan 20155 \\ E-mail: armansyah.ginting@gmail.com \\ Dosen Dept. Teknik Mesin Fakultas Teknik, Universitas Sumatera Utara ${ }^{3}$ \\ Jl. Almamater, Kampus USU Medan 20155
}

\begin{abstract}
The purpose of the research was to characterize diamond-film coating which is used as carbide tool coating material, especially coating material (diamond-film CVD), This is related to the research which reported about the functional failure of carbide tool coating material, used in dry machining process of non-ferro metal in the initial wear. The study on the characteristics of tool diamond-film coating was conducted through mechanic load approaches which occurred between the working object and tool through dry machining process used of aluminium alloy 6061 . Cutting condition was $v=350 \mathrm{~m} / \mathrm{min} ; \mathrm{f}=0.15 \mathrm{~mm} / \mathrm{put} ; \mathrm{a}=1.5 \mathrm{~mm}$ in Initial-wear phase $\left(t_{c}=1.736 \mathrm{~min}\right)$. Mechanic load was tested by using different solid testing materials. aluminum 6061 (53.3 $\mathrm{HRB} / 95 \mathrm{HV})$ and AISI 1070(93.3 HRB/200 HV), the result of the test for aluminum 6061 was abrasive wear $\mathrm{V}_{B}$ $=0.070 \mathrm{~mm}$ and in AISI 1070 was flank-wear $\mathrm{V}_{\mathrm{B}}=0.250 \mathrm{~mm}$. Used analysis was tested through micro analysis using scanning electron microscope (SEM) AND energy dispersive analysis X-Ray spectroscopy (EDAX), the result of the test was the distribution of diamond-film coating elements in aluminum 6061 testing material on the cutting conditions indicated that diamond-film coating material was still significant. Then for AISI 1070 testing material in the two cutting conditions indicated that diamond-film coating material was still significant. The conclusion of the study was that by using mechanic load, was no coating delamination in diamond-film coating of carbide tool. The phenomenon of the three approaches was the gradual disappearing of a part of the volume of diamond-film coating material which layered substrate material as the result of abrasive-coating wear.
\end{abstract}

Keywords: Dry Machining, Diamond-Film Coating- CVD Carbide Tool dan Abrasive-Coating Wear.

\begin{abstract}
Abstrak
Penelitian ini bertujuan untuk mengkarakterisasi lapisan diamond-film yang digunakan sebagai bahan pelapis pahat karbida khususnya bahan pelapis (diamond-film CVD), sehubungan dengan adanya laporan penelitian perihal kegagalan fungsi dari bahan pelapis pahat karbida yang digunakan pada proses pemesinan kering bahan non-ferro metal pada awal proses pemotongan berlangsung (initial wear). Kajian karakteristik lapisan diamond-film pahat dilakukan melalui pendekatan beban mekanik melalui proses pemesinan kering menggunakan bahan paduan aluminium 6061. Kondisi pemotongan yaitu v=350 m/min; f=0.15 mm/put; $a=1.5$ $\mathrm{mm}$ pada fasa Initial-wear $\left(\mathrm{t}_{\mathrm{c}}=1.736 \mathrm{~min}\right)$. Uji beban mekanik menggunakan bahan uji berkekerasan berbeda, Aluminium 6061 (53.3 HRB/95 HV) dan AISI 1070 (93.3 HRB/200 HV), hasil pengujian pada bahan uji Aluminium 6061 diperoleh keadaan Aus-abrasive $\mathrm{V}_{\mathrm{B}}=0.070 \mathrm{~mm}$, dan pada bahan uji AISI 1070 diperoleh keadaan Aus tepi $V_{B}=0.250 \mathrm{~mm}$, analisa menggunakan scanning electron microscope (SEM) dan energy dispersive analysis X-Ray spectroscopy (EDAX), hasil pengujian diperoleh sebaran unsur pelapis diamond-film pada bahan uji Aluminium 6061 terhadap kondisi pemotongan diperoleh keadaan unsur material pelapis diamond film masih signifikan. Kemudian pada bahan uji AISI 1070 terhadap kedua kondisi pemotongan diperoleh keadaan unsur material pelapis diamond-film signifikan. Dari hasil penelitian disimpulkan bahwa pendekatan beban mekanik tidak ditemukan peristiwa pengelupasan lapisan diamond-film pahat karbida, fenomena yang terjadi terhadap ketiga pendekatan yang dilakukan adalah peristiwa hilang bertahapnya sebagian volume material pelapis diamond-film yang melapisi material substrate akibat Aus pengikisan lapisan (abrasivecoating wear).
\end{abstract}

Katakunci: Pemesinan Kering, Lapisan Diamond-film CVD Pahat Karbida dan Aus Pengikisan Lapisan. 


\section{Pendahuluan}

Pahat karbida saat ini masih menempati posisi paling dominan pada industri pengerjaan logam serta menjadi pilihan terbaik untuk proses pemotongan logam [1]. Pahat karbida telah terbukti menghasilkan kriteria hasil pemotongan terbaik terutama pada proses pemotongan bubut. Selain menunjukkan nilai prestasi yang baik, pahat karbida juga merupakan pahat yang mempunyai nilai ekonomi yang baik [2].

Seiring pesatnya perkembangan teknologi, maka untuk maksud meningkatkan performa serta resistensi aus pahat pemotong yang digunakan untuk proses pemesinan, pahat karbida dapat semakin ditingkatkan performanya ataupun kinerjanya melalui proses pelapisan (coating). Dewasa ini teknologi pelapisan pahat dengan berbagai bahan pelapis serta metode pelapisan telah dikembangkan [3-4]. Pada teknologi pelapisan pahat pemotong tersebut, fungsi utama dari material pelapis adalah sebagai pelumas padat yang berfungsi untuk mereduksi gesekan dan panas tergenerasi selama proses pemotongan [5]. Dari kinerja tersebut jelas merupakan kerja dari bahan pelapis yang terbukti tangguh mereduksi pertumbuhan aus tepi, aus kawah dan aus yang diakibatkan oleh reaksi kimiawi antara benda kerja dan pahat. Banyak jenis metode proses rekayasa pelapisan pahat (coating), namun metode pelapisan yang paling berkembang saat ini adalah metode CVD (chemical vapour deposition) dan metode PVD (physical vapour deposition).

Untuk lebih mendapat informasi yang komprehensif tentang kinerja bahan pelapis pahat karbida yang banyak digunakan pada industri pemotongan logam khususnya untuk memproduksi produk-produk berbahan dasar aluminium, perlu dilakukan kajian terkait kinerja lapisan pahat karbida, hal tersebut sejalan dengan hasil penelitian [6], yang melaporkan bahwa performa bahan pelapis/lapisan pada pahat karbida berlapis tidak berfungsi sebagaimana yang diharapkan ketika digunakan pada operasi frais bahan non-ferro metal. Dalam laporannya menyimpulkan bahwa terjadi ragam aus yang baru dan dinamakan dengan pengelupasan pelapis (coating delamination). Hasil penelitian [6], mereka mendapati bahwa lapisan-lapisan dari bahan pelapis yang digunakan untuk melapisi dari material inti (substrate) pahat karbida terkelupas pada saat proses pemotongan logam non-ferro berlangsung, mereka melaporkan secara rinci bahwa lapisan tersebut terkelupas pada saat awal proses pemotongan atau pada saat awal terjadinya aus (initial wear).

Pengelupasan lapisan (coating delamination) adalah mekanisme keausan pahat yang dapat disebabkan oleh beban mekanik (impact), beban thermal atau interaksi secara kimiawi antara bahan benda kerja dan pahat. Pada proses aus ini, lapisan pahat yang menyelimuti bahan inti pahat (substrate) terkelupas akibat adanya tekanan/gaya potong atau thermal maupun reaksi kimia yang bekerja pada pahat yang melebihi kemampuannya (adhesive-force) pada saat pemotongan. Jika pengelupasan terjadi, artinya lapisan pahat sama sekali tidak memiliki fungsi, maka ekspektasi penggunaan bahan pelapis pada pahat yang dimaksudkan untuk meningkatkan performa pahat dan meningkatkan produktivitas serta laju pemesinan tidak terwujud.

Objek permasalahan yang dikaji pada penelitian dengan topik pemesinan kering dibatasi hanya pada subjek penelitian yang dikonsentrasikan pada kajian karakteristik lapisan diamond-film pahat karbida saat digunakan untuk memotong benda kerja non ferro metal. Benda kerja yang digunakan dalam penelitian ini adalah paduan aluminium berkekerasan rendah berpengenal Al-6061 AlMg1SiCu yang biasa digunakan pada aplikasi konstruksi dan biasa terdapat pada perangkat-perangkat penerbangan, armada laut, piston, piston rem serta aplikasi lainnya, dari sifat fisiknya benda kerja yang digunakan dalam penelitian ini berkekerasan 53.3/95 HV. Kajian karakteristik lapisan diamond-film pahat dilakukan melalui pendekatan beban mekanik. Pembatasan masalah pada kajian karakteristik lapisan diamond film mengandung konsep pemahaman yaitu pengujian terhadap aspek beban mekanik dilakukan proses pemesinan dengan menggunakan dua jenis bahan uji yang memiliki tingkat kekerasan bahan berbeda yaitu: bahan uji non-ferro metal Aluminium $6061 \mathrm{AlMg} 1 \mathrm{SiCu}$ (53.3 HRB/95 HV) dan bahan uji ferro metal Baja AISI-1070 (93.3 HRB/200 HV).

Penelitian ini bertujuan untuk mengetahui karakteristik lapisan film diamond yang digunakan sebagai bahan pelapis pahat karbida dari aspek beban mekanik, khususya bahan pelapis (diamond film) dan bahan substrat (WC/Co) pahat karbida pada umumnya.

Hasil penelitian ini diharapkan dapat memberi manfaat bagi dunia akademik dan industri pemotongan logam pada umumnya serta bagi peneliti pada khususnya, adapun manfaat tersebut adalah guna memberi kontribusi pada penyediaan data dan informasi perencanaan proses bubut kering bahan non ferro metal, khususnya informasi karakteristik lapisan diamond-film yang digunakan sebagai bahan pelapis pahat.

\section{Studi Literatur}

\section{Pemesinan Kering}

Pada umumnya proses pemesinan untuk memfabrikasi komponen-komponen mesin dilakukan dengan metode proses pemesinan basah (wet machining process) yang menggunakan cairan pendingin (coolant). Pada metode ini cairan pemotongan dialirkan ke kawasan pemotongan 
selama proses pemesinan dengan tujuan menurunkan suhu pemotongan dan melumasi bagian-bagian pemesinan sehingga diharapkan permukaan hasil proses pemesinan memiliki integritas permukaan (surface integrity) yang baik. Fenomena kegagalan pahat serta penggunaan cairan pemotongan pada pengerjaan pemotongan logam adalah masalah yang telah banyak mendapat perhatian untuk dikaji, karena dalam kaitannya sangat berpengaruh terhadap kekasaran permukaan, geometri, mekanisme aus serta umur pahat hasil pemesinan [8].

Alternatif dari pemesinan basah adalah pemesinan kering, pemesinan kering (dry cutting) adalah proses pemotongan logam yang dilakukan tanpa cairan pemotongan atau cairan pelumasan yang digunakan sebagai media pendingin ataupun media pelumas. Pemesinan kering diakui mampu mengatasi masalah pada dampak yang telah di uraikan diatas, karena selain tidak ada cairan pemotongan bekas yang akan mencemari lingkungan juga tidak ada kabut partikel cairan pemotongan yang akan membahayakan operator.

\section{Karakteristik Terminologi Proses Bubut}

Membubut merupakan salah satu operasi pemesinan yang paling umum dan banyak ditemui pada industri pemotongan logam. Pada proses ini benda kerja yang dicekam pada chuck berotasi pada sumbunya, sedang pahat sebagai alat potong bergerak translasi menyayat benda kerja sepanjang sumbu benda kerja atau terhadap diameternya. skematis dari sebuah proses bubut dimana putaran poros utama (n), pemakanan (f) dan kedalaman potong (a).

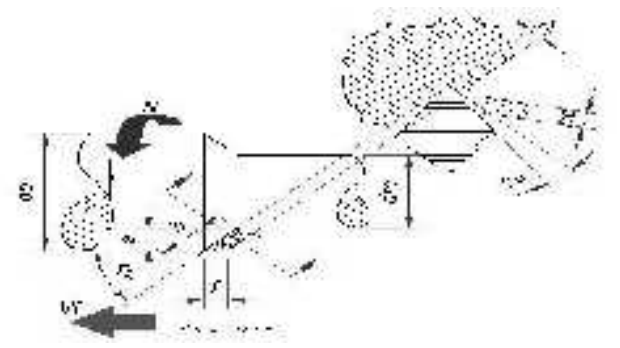

Sumber : Kalpakjian and Schmid, (2006)

Gambar 1. Skematis Proses Bubut

Elemen dasar pada proses bubut diketahui berdasarkan Gambar 2. berikut ini :

1. Kecepatan potong (cutting speed): $v(\mathrm{~m} / \mathrm{min})$

2. Kecepatan makan (feeding speed): $v f(\mathrm{~mm} / \mathrm{min})$

3. Kedalaman potong (depth of cut): $a(\mathrm{~mm})$

4. Waktu pemotongan (cutting time): $t_{c}$ (min)

5. Laju pembuangan geram (material removal rate): $\mathrm{Z}$ (cm3/min).

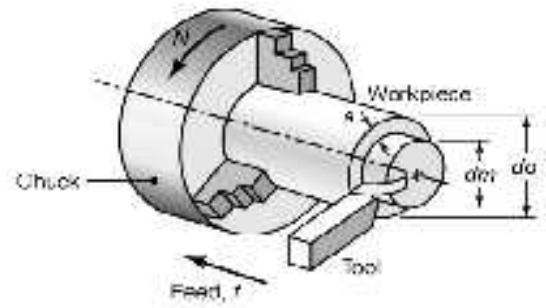

Sumber : Kalpakjian, (2003).

Gambar 2. Proses Bubut

Geometri benda kerja:

$d o=$ diameter awal $(\mathrm{mm})$

$d m=$ diameter akhir $(\mathrm{mm})$

$l t$ = panjang pemesinan $(\mathrm{mm})$

Geometri pahat:

$k r=$ sudut potong utama (o)

$\gamma o=$ sudut geram (o)

Kondisi pemesinan

$a=$ kedalaman potong

$a=\frac{a c-a m}{2}(\mathrm{~mm})$

$f=$ pemakanan (mm/putaran)

$N=$ putaran poros utama (rpm)

Dengan diketahuinya besaran-besaran diatas, sehingga kondisi pemotongan dapat diperoleh sebagai berikut:

Laju pemotongan

$v=\frac{w_{a} n}{\text { zWW }}$

Dimana

$d=$ diameter rata-rata

$a+a m$

$d=\overline{2}(\mathrm{~mm})$

Laju pemakanan

$v f=f . N(\mathrm{~mm} / \mathrm{min})$

Waktu pemotongan

$t c=\frac{t \varepsilon}{v_{I}}(\min )$

\section{Bahan Pahat}

Prinsip dasar pemesinan adalah kemampuan ketangguhan (toughness) pahat terhadap benda kerja. Banyak perkembangan pada bahan pahat guna untuk semakin meningkatkan kemampumesinan, dimana geometri dan bahan pahat merupakan hal yang perlu di pertimbangkan. Syarat bahan pahat yang harus 
dipenuhi mencakup: kekerasan, ketangguhan, rendah sifat adhesi, rendah penyerapan dan tahan aus.

\section{Pelapisan Pahat}

Salah satu fungsi utama dari lapisan (coated) adalah untuk meningkatkan kinerja dari pahat tersebut [8]. Gambar 3 menunjukkan tingkat pelapisan pahat karbida yaitu single layer, two layer dan multilayer [12]. Banyak jenis metode proses rekayasa pelapisan (coating) permukaan bahan yang bertujuan untuk menambah kekerasan, tahan korosi dan tahan terhadap keausan [27], diantaranya metoda evavorasi, chemical vapour deposition (CVD), physical vapour deposition (PVD), karburasi, nitridasi, implantasi ion, industri listrik dan sputtering.

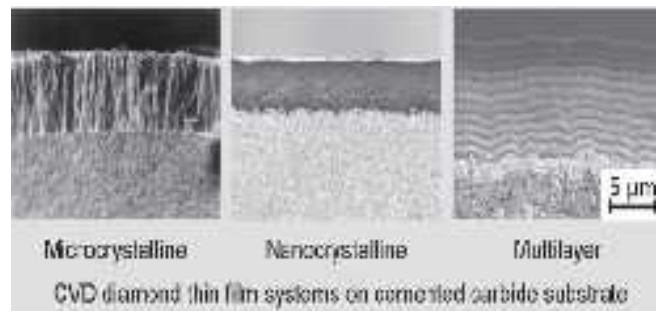

Sumber : E. Uhlmann (1)*, J. Koenig, (2009)

Gambar 3. Tipe Pelapisan Film Diamond CVD

\section{Karakteristik Kegagalan Pahat}

Efek kegagalan pahat ditinjau dari performa secara teknik yaitu berkaitan dengan konsekuensi menurunnya akurasi dimensi, meningkatnya kekasaran permukaan, meningkatnya suhu pemotongan, besarnya gaya potong, getaran yang meningkat, menurunnya effisiensi produksi dan meningkatnya ongkos produksi. Karakteristik kegagalan pahat dan mekanismenya dapat menyebabkan umur pahat berakhir lebih cepat (premature end), pada Gambar 4. berikut dapat dilihat ragam bentuk kegagalan pahat.

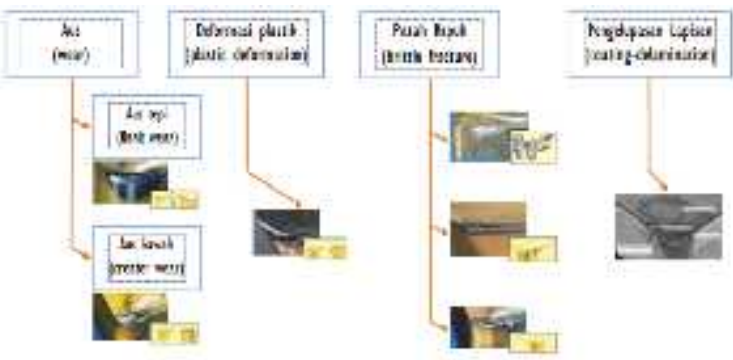

Sumber: ISO 3685 (1993); J. Hu, et.al, (2008)

Gambar 4. Ragam bentuk kegagalan pahat

1. Aus (wear)

Aus (wear) di karakteristikan: a. Aus Tepi (flank wear)

b. Aus Kawah (crater wear)

2. Deformasi Plastik (plastic deformation)

3. Patah Rapuh (brittle fracture)

Patah rapuh pahat diklasifikasikan atas:

a. Penyerpihan (chipping):

b. Aus takikan (notch wear):

c. Retak (cracking):

d. Aus ujung pahat (nose wear):

Kriteria kegagalan adalah apabila terjadi Aus tepi (VB) dan berulang pada kecepatan potong yang berbeda terhadap fungsi waktu, Batas keausan tepi pahat adalah $0.3 \mathrm{~mm}$ pada waktu pemotongan tidak kurang dari 5 menit [18], pada Gambar 2.10 menjelaskan besar pertumbuhan Aus tepi $\left(\mathrm{V}_{\mathrm{B}}\right)$ berulang terhadap fungsi waktu.

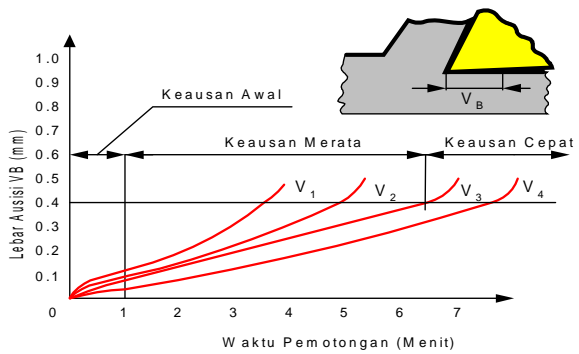

Sumber: Boothroyd \& Kinght 1989

Gambar 5. Kurva kedalaman aus sis berulang terhadap fungsi waktu

4. Pengelupasan Lapisan (coating delamination)

Pengelupasan lapisan (coating delamination) merupakan kejadian hilangnya bagian pahat dalam bentuk lapisan dari permukaan pahat. Secara substantif dinyatakan bahwa adalah peristiwa kepindahan lokal atau pealing material untuk membuka substrate pahat, bentuk pengelupasan pelapis pada Gambar 6 .

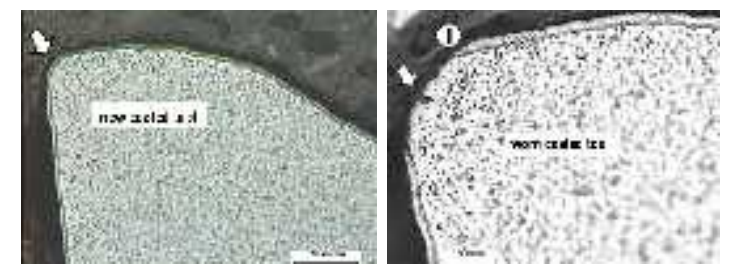

Sumber : Nouari dan Ginting, (2006)

Gambar 6. Pengelupasan Lapisan

\section{Metode}

\section{Bahan}

Penelitian ini menggunakan bahan uji Aluminium $6061 \mathrm{AlMg} 1 \mathrm{SiCu}$, berbentuk billet, dengan panjang $220 \mathrm{~mm}$ dan diameter $132 \mathrm{~mm}$. 
Material ini dipilih karena material ini sangat aplikatif dan biasa terdapat pada: perangkatperangkat penerbangan, armada laut, piston, piston rem serta aplikasi lainnya [21]. Benda kerja terdapat pada Gambar 7, komposisi kimia dan kekerasan material ini dapat dilihat sebagaimana tertera padat Tabel 1 dan Tabel 2 berikut ini.

Tabel 1. Komposisi kimia bahan Al-6061 AlMg1SiCu

\begin{tabular}{|c|c|c|c|c|c|c|c|c|c|c|}
\hline $\begin{array}{l}\text { Al } \\
(\%)\end{array}$ & $\begin{array}{c}\mathrm{Si} \\
(\%)\end{array}$ & $\begin{array}{c}\mathrm{Fe} \\
(\%)\end{array}$ & $\begin{array}{l}\mathrm{Cu} \\
\%)\end{array}$ & $\begin{array}{l}\text { Mn } \\
(\%\end{array}$ & $\begin{array}{c}\mathbf{M g} \\
(\% \\
) \\
\end{array}$ & $\begin{array}{c}\text { Zn } \\
(\% \\
) \\
\end{array}$ & $\begin{array}{c}\mathrm{Cr} \\
(\%)\end{array}$ & $\begin{array}{l}\mathrm{Ni} \\
\%)\end{array}$ & $\begin{array}{r}\mathrm{Ti} \\
(\% \\
\\
\end{array}$ & $\begin{array}{l}\mathrm{Ca} \\
(\%)\end{array}$ \\
\hline 98.1 & $\begin{array}{c}0.57 \\
7\end{array}$ & $\begin{array}{l}0.0 \\
01\end{array}$ & $\begin{array}{l}0.1 \\
63\end{array}$ & $\begin{array}{l}0.0 \\
34\end{array}$ & $\begin{array}{l}0.9 \\
29\end{array}$ & $\begin{array}{l}0.0 \\
50\end{array}$ & 0.089 & $\begin{array}{l}0.0 \\
02\end{array}$ & $\begin{array}{l}0.0 \\
11\end{array}$ & 0.004 \\
\hline $\begin{array}{c}\mathbf{P b} \\
(\%)\end{array}$ & $\begin{array}{l}\text { Sn } \\
(\%)\end{array}$ & $\underset{(\%)}{\mathbf{V}}$ & $\begin{array}{l}\mathbf{B i} \\
\%)\end{array}$ & $\begin{array}{c}\mathbf{Z r} \\
\text { ) }\end{array}$ & $\begin{array}{c}\text { Ga } \\
(\% \\
)\end{array}$ & $\begin{array}{l}\text { Co } \\
(\% \\
)\end{array}$ & $\underset{(\%)}{\mathbf{H g}}$ & $\begin{array}{l}\text { In } \\
\%)\end{array}$ & $\begin{array}{c}\mathbf{S b} \\
(\% \\
)\end{array}$ & $\begin{array}{l}\mathbf{L a} \\
(\%)\end{array}$ \\
\hline $\begin{array}{c}0.00 \\
1\end{array}$ & $\begin{array}{c}0.00 \\
2\end{array}$ & $\begin{array}{l}0.0 \\
09\end{array}$ & $\begin{array}{l}0.0 \\
03\end{array}$ & $\begin{array}{l}0.0 \\
01\end{array}$ & $\begin{array}{l}0.0 \\
07\end{array}$ & $\begin{array}{l}0.0 \\
02\end{array}$ & 0.002 & $\begin{array}{l}0.0 \\
03\end{array}$ & $\begin{array}{l}0.0 \\
10\end{array}$ & 0.001 \\
\hline
\end{tabular}

Sumber: Lab. Pengujian Bahan, Unimed. (2014)

Tabel 2. Kekerasan bahan Al-6061 AlMg1SiCu

\begin{tabular}{|c|c|c|c|c|}
\hline Material & $\begin{array}{c}\text { Test } \\
\text { I }\end{array}$ & $\begin{array}{c}\text { Test } \\
\text { II }\end{array}$ & $\begin{array}{c}\text { Test } \\
\text { III }\end{array}$ & $\begin{array}{c}\mathrm{HRB} / \\
\mathrm{HV}\end{array}$ \\
\hline $\begin{array}{c}\text { Aluminium } 6061 \\
\text { AlMg1SiCu }\end{array}$ & 53.0 & 53.5 & 53.0 & $\begin{array}{l}53.3 / 9 \\
5 \mathrm{HV}\end{array}$ \\
\hline
\end{tabular}

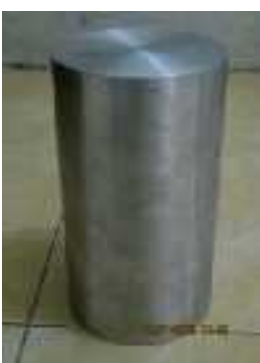

Gambar 7. Bahan benda uji Al-6061

Baja AISI-1070 berbentuk billet, ukuran efektif panjang $210 \mathrm{~mm}$ dan diameter $41 \mathrm{~mm}$, biasa digunakan untuk konstruksi jembatan, pegas dll. Bahan benda kerja terdapat pada Gambar 8 . Komposisi kimia dan kekerasan dari meterial ini dipaparkan pada Tabel 3. dan Tabel 4. berikut ini

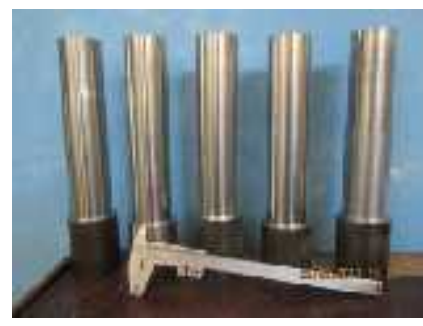

Gambar 8. Bahan benda Uji AISI-1070

Tabel 3. Komposisi kimia AISI-1070

\begin{tabular}{cccccccccccc}
\hline $\begin{array}{c}\mathbf{F e} \\
(\%)\end{array}$ & $\begin{array}{c}\mathbf{C} \\
(\%)\end{array}$ & $\begin{array}{c}\mathbf{S i} \\
(\%)\end{array}$ & $\begin{array}{c}\mathbf{M n} \\
(\%)\end{array}$ & $\begin{array}{c}\mathbf{p} \\
(\%)\end{array}$ & $\begin{array}{c}\mathbf{s} \\
(\%)\end{array}$ & $\begin{array}{c}\mathbf{C r} \\
(\%\end{array}$ & $\begin{array}{c}\mathbf{M} \\
\mathbf{0} \\
(\%\end{array}$ & $\begin{array}{c}\mathbf{N i} \\
(\%)\end{array}$ & $\begin{array}{c}\mathbf{N i} \\
(\%)\end{array}$ & $\begin{array}{c}\mathbf{A l} \\
(\%)\end{array}$ \\
\hline & $\begin{array}{c}0.79 \\
6\end{array}$ & $\begin{array}{c}0.25 \\
8\end{array}$ & $\begin{array}{c}0.79 \\
0\end{array}$ & $\begin{array}{c}0.02 \\
5\end{array}$ & 0.011 & $\begin{array}{c}0.1 \\
51\end{array}$ & $\begin{array}{c}0.0 \\
89\end{array}$ & $\begin{array}{c}0.00 \\
8\end{array}$ & $\begin{array}{c}0.03 \\
9\end{array}$ & $\begin{array}{c}0.05 \\
5\end{array}$ \\
\hline
\end{tabular}

\begin{tabular}{cccccc}
\hline $\begin{array}{c}\mathrm{Co} \\
(\%)\end{array}$ & $\begin{array}{c}\mathrm{Cu} \\
(\%)\end{array}$ & $\begin{array}{c}\mathbf{N b} \\
(\%)\end{array}$ & $\begin{array}{c}\mathbf{T i} \\
(\%)\end{array}$ & $\begin{array}{c}\mathbf{v} \\
(\%)\end{array}$ & $\begin{array}{c}\mathbf{w} \\
(\%)\end{array}$ \\
\hline 0.00 & 0.00 & 0.00 & 0.00 & 0.00 & 0.015 \\
1 & 9 & 5 & 5 & 5 & \\
\hline
\end{tabular}

Sumber: Lab. Pengujian bahan, Unimed. (2014)

Tabel 4. Kekerasan Baja AISI 1070

\begin{tabular}{ccccc}
\hline Material & $\begin{array}{c}\text { Test } \\
\text { I }\end{array}$ & $\begin{array}{c}\text { Test } \\
\text { II }\end{array}$ & $\begin{array}{c}\text { Test } \\
\text { III }\end{array}$ & $\begin{array}{c}\text { HRB/ } \\
\text { HV }\end{array}$ \\
\hline Baja AISI 1070 & 93.5 & 93.0 & 93.5 & $\begin{array}{c}93.3 / 2 \\
00 \mathrm{HV}\end{array}$ \\
\hline
\end{tabular}

\section{Pahat potong}

Pahat pemotong yang digunakan pada penelitian ini yaitu jenis karbida berlapis diamond film (single layer). Menurut berpengenal standard ISO klasifikasi N10 maka pahat ini digunakan untuk bahan non ferro metal. Bentuk dan ukuran sesuai standar ISO yaitu DCGX 11 T3 04-AL 1810. spesifikasi taknis dapat dilihat pada Tabel 5 dan Gambar 9, berikut ini.

\begin{tabular}{|c|c|c|c|c|c|c|c|}
\hline \multicolumn{5}{|c|}{ Komposisi } & \multicolumn{3}{|c|}{$\begin{array}{l}94 \% \mathrm{WC} \\
6 \% \mathrm{Co}\end{array}$} \\
\hline $\begin{array}{l}\text { Coating } \\
\text { Thickness } \\
(\mu \mathrm{m})\end{array}$ & $\begin{array}{c}\text { Grai } \\
\text { n } \\
\text { Size } \\
(\mu \mathrm{m})\end{array}$ & $\begin{array}{l}\text { Hardn } \\
\text { ess } \\
(\mathrm{HV})\end{array}$ & $\begin{array}{l}\text { Coating } \\
\text { Spesificati } \\
\quad \text { on }\end{array}$ & $\begin{array}{l}\text { Radiu } \\
\text { s Nose } \\
(\mathbf{m m})\end{array}$ & $\begin{array}{c}\text { Max } \\
\text { Dept } \\
\text { of } \\
\text { Cut } \\
(\mathrm{mm})\end{array}$ & $\begin{array}{c}\text { Max } \\
\text { Cutting } \\
\text { Speed } \\
\left(\begin{array}{c}\text { V=m/mi } \\
\text { n) }\end{array}\right.\end{array}$ & $\begin{array}{c}\text { Max } \\
\text { Feed } \\
\text { ing } \\
(\mathbf{m m} \\
)\end{array}$ \\
\hline 6.0 & $\begin{array}{l}1.4- \\
2.5\end{array}$ & 1710 & $\begin{array}{c}\text { Diamond } \\
\text {-film } \\
\text { CVD }\end{array}$ & 0.4 & 1.5 & 2000 & 0.2 \\
\hline
\end{tabular}

Sumber: Sandvik Coromant, (2012).

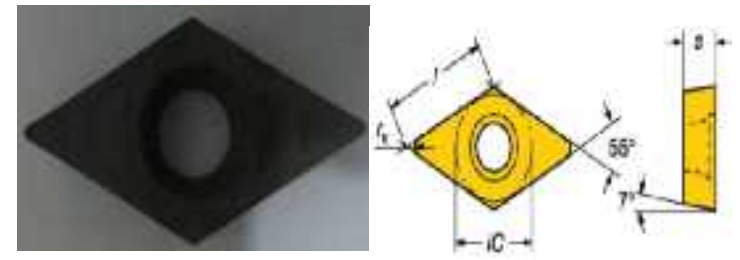

Gambar 9. Pahat dan Geoetri ISO-N10 DCGX 11 T3 04-AL 1810

\section{Pemegang pahat (tool-holder)}

Pemegang pahat yang digunakan adalah jenis SDJC R-S 2020K $11\left(93^{\circ}\right)$ yang dikhususkan untuk proses bubut dan dapat dilihat pada gambar 3.4.
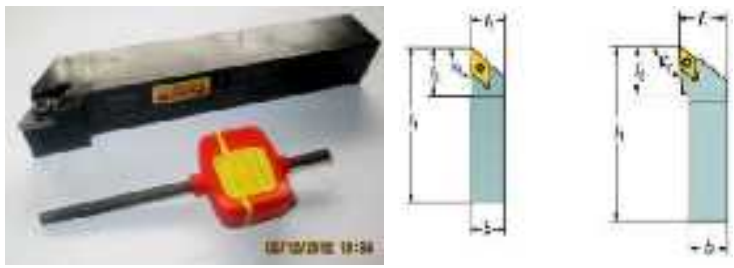

Gambar 10. Pemegang pahat dan Geometri jenis SDJC R-S 2020K 11

Alat

Portable dan Rockwell hardness tester

Untuk mengetahui nilai kekerasan bahan uji, benda uji diperiksa terlebih dahulu menggunakan Portable hardness tester yang kemudian pengujian dibandingkan dengan hasil pengukuran kekerasan menggunakan Rockwell hardness tester untuk 
mendapatkan validasi data, spesifikasi data teknis dan pemeriksaan kekerasan benda uji dapat dilihat pada Gambar 11 dan Gambar 12 serta Tabel 6 berikut ini.
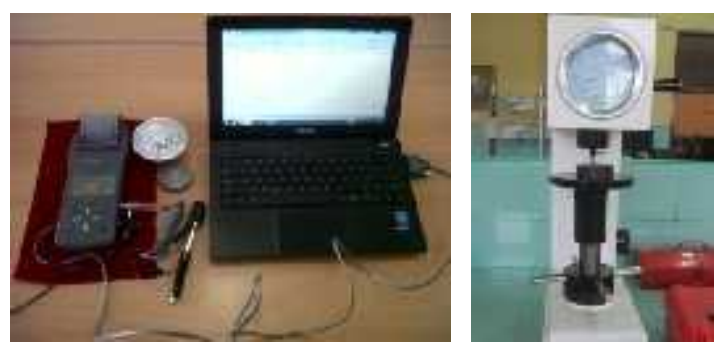

Gambar 11. Portable hardness test TH160 dan Rockwell hardness test TH500

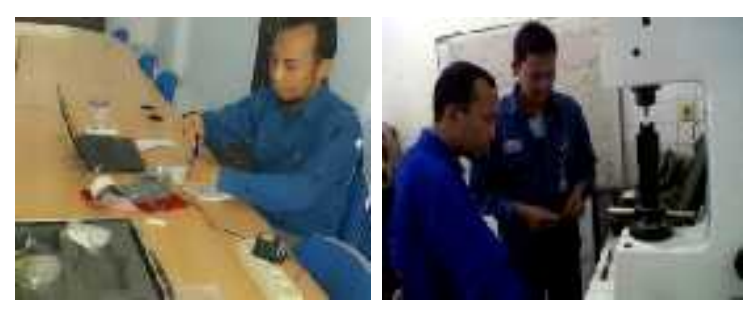

Gambar 12. Pemeriksaan kekerasan benda uji

\section{Foundry Master}

Untuk mengetahui prosesntase besaran kandungan unsur pada bahan uji, dilakukan pengujian komposisi menggunakan mesin Foundry Master, seperti yang terlihat pada Gambar 13 berikut ini

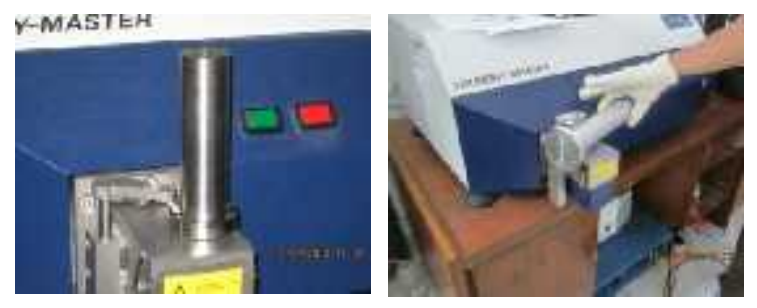

Gambar 13. Pemeriksaan komposisi benda uji

\section{Mesin Bubut}

Pemesinan dilakukan menggunakan mesin bubut CD 6260-C, spesifikasi data teknis sebagaimana dilihat pada Gambar 14 berikut.

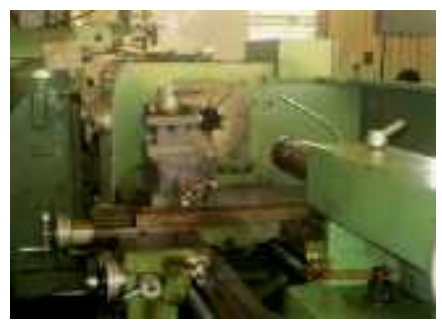

Gambar 14. Mesin bubut CD 6260-C

\section{USB Digital Microscope}

Untuk mengambil data gambar keausan awal pahat yang terjadi setelah proses pemesinan digunakan USB Digital Microscope Cameras, lensa dual Axis $27 \mathrm{x} / \mathrm{WO}=8 \mathrm{~mm}$ dan $100 \mathrm{x} / \mathrm{WO}=2 \mathrm{~mm}$ micro-scope le lense. USB digital microscope dapat dilihat pada, Gambar 15 berikut ini.

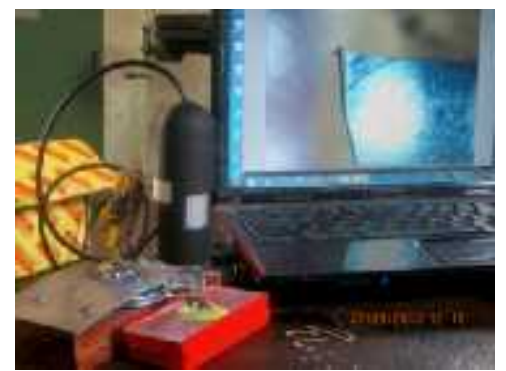

Gambar 15. USB digital microscope

Scanning Electron Microscope (SEM)-Energy Dispersive Spectroscopy (EDS)

Scanning electron microscope (SEM), electron microscope mempunyai perbesaran sampai $20 \mathrm{ribu}$ kali, elektron digunakan sebagai pengganti cahaya. SEM digunakan untuk studi detail arsitektur permukaan sel (struktur renik lainnya), obyek diamati secara tiga dimensi. Topografi pahat maupun mikrostrukturnya dan untuk menganalisa permukaan dan tekstur (kekerasan, reflektivitas) termasuk morfologi dan komposisi digunakan energy dispersive spectroscopy (EDS). Peralatan scanning electron microscope (SEM)- energy dispersive spectroscopy (EDS) serta spesifikasi dari peralatan scanning electron microscope (SEM) dapat dilihat pada Gambar 16. berikut ini.
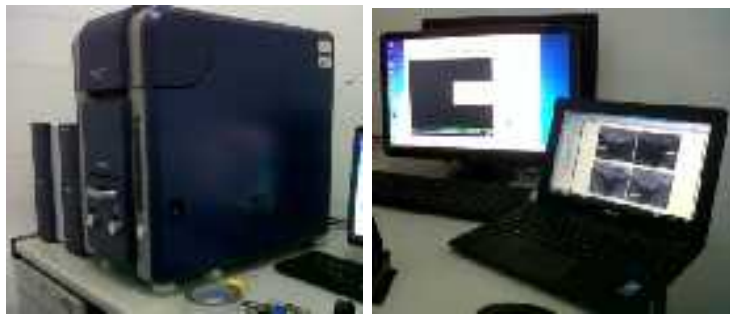

Gambar 16. Scanning electron microscopy (SEM-EDS) TM-3000

\section{Rancangan Kegiatan Penelitian}

Setup Pemesinan

1. Menyiapkan peralatan pengambilan data diantaranya:

a. Mesin bubut konvensional CD 6260-C serta menyiapkan pahat insert karbida un-coated dan berlapis diamond-film.

b. Pemegang pahat/tool holder.

c. Bahan uji Al 6061 dan AISI-1070.

d. USB digital mikroskop.

2. Memeriksa kondisi mesin yang harus benar-benar kaku dan tidak speeling. 
3. Menyesuaikan diameter benda uji pada putaran mesin (rpm) yang ada pada mesin bubut CD 6260-C.

4. Memulai langkah pemesinan dengan menentukan putaran mesin (rpm), pemakanan (f) dan kedalaman potong (a).

5. Menjalankan proses pemesinan sesuai dengan kondisi pemotongan.

6. Mengambil data awal mode aus dengan USB digital microscope dengan cara sbb:

a. Setelah pemesinan dilakukan dengan panjang pemesinan (lt) sesuai dengan benda kerja maka pahat diletakkan diatas plestisin.

b. Mengatur focus sampai gambar keausan pahat terlihat jelas.

c. Capture gambar buka di file desktop.

Mekanisme Pengujian Beban Mekanik

Pengujian pada aspek beban mekanik melakukan operasi bubut kering pada fasa Initial-wear menggunakan dua jenis bahan uji yang memiliki kekerasan bahan yang berbeda sesuai hasil pengujian komposisi dan nilai kekerasan bahan uji yaitu: Aluminium $6061 \mathrm{AlMg} 1 \mathrm{SiCu}$ adalah 53.3 HRB dan Baja AISI-1070 adalah 93.3 HRB.

Metode Analisa Beban Mekanik

Analisa pengujian terhadap kondisi pahat untuk mengetahui mekanisme dan mengukur kegagalan setelah mengalami perlakuan, terlebih dahulu dilakukan menggunakan USB digital microscope, yang selanjutnya foto topografi permukaan dan diukur dengan menggunakan SEM-EDS.

\section{Diagram Alir Penelitian}

Tahapan-tahapan proses penelitian ini digambarkan kedalam diagram alir penelitian diperlihatkan pada Gambar 17.

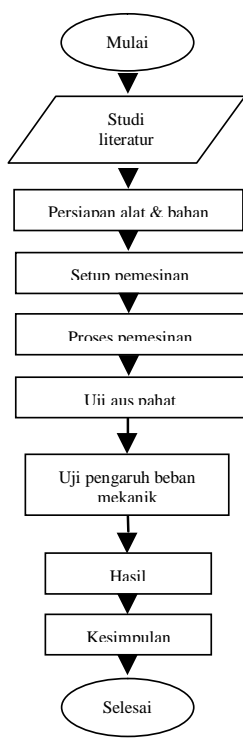

Gambar 17. Diagram Alir Penelitian

\section{Hasil dan Pembahasan}

Pahat Karbida Un-coated

Pahat Karbida Un-coated Pemesinan Bahan Uji Aluminium 6061

Tabel 6. Hasil uji pahat karbida un-coated pemesinan bahan uji Al-

\begin{tabular}{cccccccc}
\hline $\begin{array}{c}\mathbf{V} \\
(\mathbf{m} / \mathbf{m i} \\
\mathbf{n})\end{array}$ & $\begin{array}{c}\mathbf{F} \\
(\mathbf{m m} / \mathbf{r} \\
\mathbf{a d})\end{array}$ & $\begin{array}{c}\mathbf{a} \\
(\mathbf{m m})\end{array}$ & $\begin{array}{c}\mathbf{d} \\
(\mathbf{m} \\
\mathbf{m})\end{array}$ & $\begin{array}{c}\mathbf{n} \\
(\mathbf{r p m})\end{array}$ & $\begin{array}{c}\mathbf{I t} \\
(\mathbf{m m})\end{array}$ & $\begin{array}{c}\mathbf{t}_{\mathbf{c}} \\
(\mathbf{m i n})\end{array}$ & $\begin{array}{c}\mathbf{V B} \\
(\mathbf{m m}\end{array}$ \\
\hline 350 & 0.15 & 1.5 & 132 & 845 & 55 & 0.434 & 0.000 \\
350 & 0.15 & 1.5 & 132 & 845 & 110 & 0.868 & 0.020 \\
350 & 0.15 & 1.5 & 132 & 845 & 165 & 1.302 & 0.030 \\
350 & 0.15 & 1.5 & 132 & 845 & 220 & 1.736 & 0.050 \\
350 & 0.15 & 1.5 & 132 & 845 & 275 & 2.170 & 0.060 \\
350 & 0.15 & 1.5 & 132 & 845 & 330 & 2.604 & 0.070 \\
350 & 0.15 & 1.5 & 132 & 845 & 385 & 3.037 & 0.073 \\
350 & 0.15 & 1.5 & 132 & 845 & 440 & 3.471 & 0.079 \\
350 & 0.15 & 1.5 & 132 & 845 & 495 & 3.905 & 0.086 \\
350 & 0.15 & 1.5 & 132 & 845 & 550 & 4.339 & 0.088 \\
350 & 0.15 & 1.5 & 132 & 845 & 605 & 4.773 & 0.091 \\
350 & 0.15 & 1.5 & 132 & 845 & 660 & 5.207 & 0.100 \\
\hline
\end{tabular}

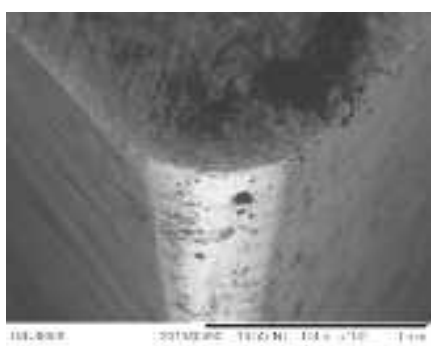

Gambar 18. Penampang pahat karbida un-coated original

Pahat karbida un-coated original dengan komposisi material inti (substrate) yaitu: $\mathrm{WC}=94 \%$ dan $\mathrm{Co}=6 \%$. Pahat karbida un-coated didesain khusus untuk pemesinan bubut dengan data rekomendasi pemotongan yaitu mampu melakukan pemotongan kecepatan (V) hingga $2000 \mathrm{~m} / \mathrm{min}$ dengan kedalaman potong (a) hingga $1.5 \mathrm{~mm}$ dan pemakanan (f) hingga $0.20 \mathrm{~mm} / \mathrm{rad}$.

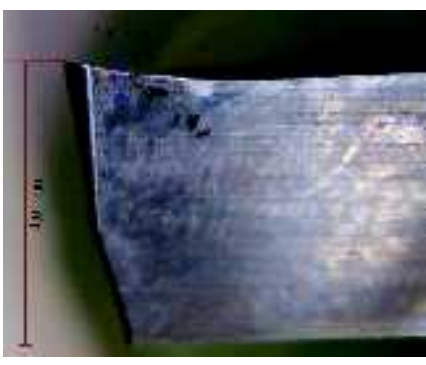

Gambar 19. Aus tepi pahat karbida un-coated, bahan uji Al-6061, Kondisi: $\mathrm{V}=350 \mathrm{~m} / \mathrm{min}\left|\mathrm{t}_{\mathrm{c}}=5.207 \mathrm{~min}\right| \mathrm{V}_{\mathrm{B}}=0.100$ $\mathrm{mm}$. 


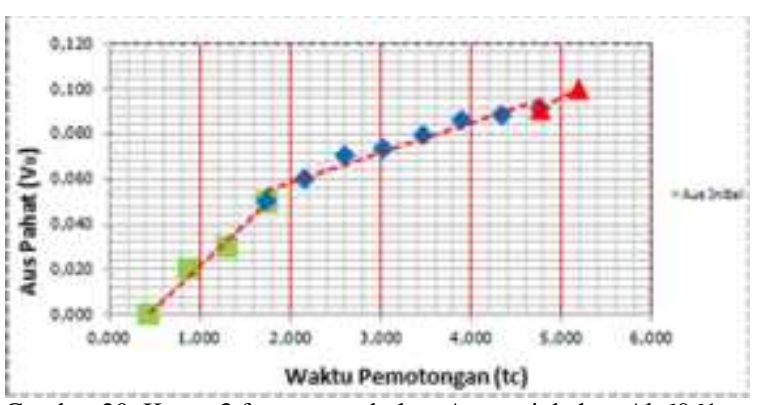

Gambar 20. Kurva 3 fasa pertumbuhan Aus tepi, bahan Al-6061

Kondisi: $\mathrm{V}=350 \mathrm{~m} / \mathrm{min} ; \mathrm{f}=0.15 \mathrm{~mm} / \mathrm{rad} ; \mathrm{a}=1.5 \mathrm{~mm}$

Gambar 19 dan Gambar 20 pada pemesinan bahan uji Al-6061, menjelaskan keausan pahat dan kurva 3 fasa laju pertumbuhan Aus tepi, Terhadap hasil pengukuran Aus tepi pahat ditetapkan masih dalam batas toleransi Aus pahat yaitu: $\mathrm{V}_{\mathrm{B}}>0.3 \mathrm{~mm}$ (dibawah $\mathrm{V}_{\mathrm{Bmax}}$ ) dalam waktu pemotongan tidak kurang 5 min, [18].

Pahat Karbida Un-coated Pemesinan Bahan Uji Baja AISI 1070

Tabel 7. Hasil uji pahat karbida un-coated pemesinan bahan uji

\begin{tabular}{|c|c|c|c|c|c|c|c|}
\hline \multicolumn{8}{|c|}{ AISI-1070 } \\
\hline$\underset{(\mathbf{m} / \mathbf{m i n})}{\mathbf{V}}$ & $\begin{array}{c}\underset{f}{f} \\
(\mathbf{m m} / \mathbf{r} \\
\mathbf{a d})\end{array}$ & $\underset{(\mathbf{m m}}{\mathbf{a}}$ & $\underset{(\mathbf{m m})}{\mathbf{d}}$ & $\begin{array}{c}\mathbf{n} \\
(\mathbf{r p m} \\
)\end{array}$ & $\begin{array}{c}\text { It } \\
(\mathbf{m m} \\
)\end{array}$ & $\underset{(\mathbf{m i n})}{\mathbf{t}_{\mathrm{c}}}$ & $\underset{(\mathbf{m m})}{\mathrm{VB}}$ \\
\hline 70 & 0.15 & 1.5 & 41 & 545 & 30 & 0.367 & 0.000 \\
\hline 70 & 0.15 & 1.5 & 41 & 545 & 60 & 0.734 & 0.000 \\
\hline 70 & 0.15 & 1.5 & 41 & 545 & 90 & 1.101 & 0.020 \\
\hline 70 & 0.15 & 1.5 & 41 & 545 & 120 & 1.468 & 0.021 \\
\hline 70 & 0.15 & 1.5 & 41 & 545 & 150 & 1.835 & 0.026 \\
\hline 70 & 0.15 & 1.5 & 41 & 545 & 180 & 2.202 & 0.043 \\
\hline 70 & 0.15 & 1.5 & 41 & 545 & 210 & 2.569 & 0.091 \\
\hline 70 & 0.15 & 1.5 & 41 & 545 & 240 & 2.936 & 0.100 \\
\hline 70 & 0.15 & 1.5 & 41 & 545 & 270 & 3.303 & 0.133 \\
\hline 70 & 0.15 & 1.5 & 41 & 545 & 300 & 3.67 & 0.151 \\
\hline 70 & 0.15 & 1.5 & 41 & 545 & 330 & 4.037 & 0.160 \\
\hline 70 & 0.15 & 1.5 & 41 & 545 & 360 & 4.404 & 0.170 \\
\hline 70 & 0.15 & 1.5 & 41 & 545 & 390 & 4.771 & 0.198 \\
\hline 70 & 0.15 & 1.5 & 41 & 545 & 420 & 5.138 & 0.230 \\
\hline
\end{tabular}

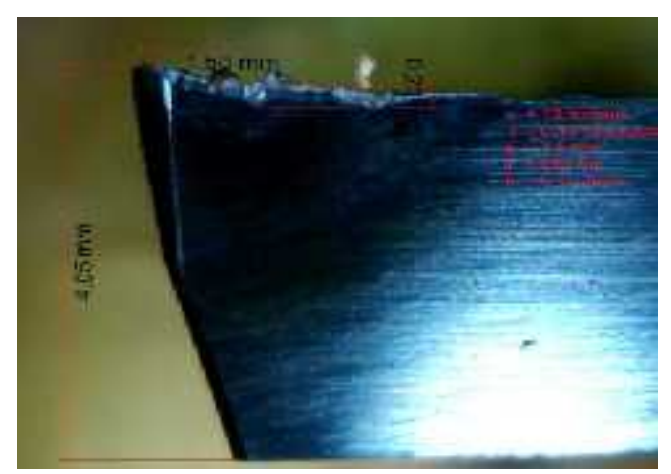

Gambar 21. Kegagalan pahat karbida un-coated pemesinan bahan uji AISI-1070 Kondisi: $\mathrm{V}=70 \mathrm{~m} / \mathrm{min} \mid \mathrm{t}_{\mathrm{c}}=5.138$ $\min \mid \mathrm{V}_{\mathrm{B}}=0.230 \mathrm{~mm}$.

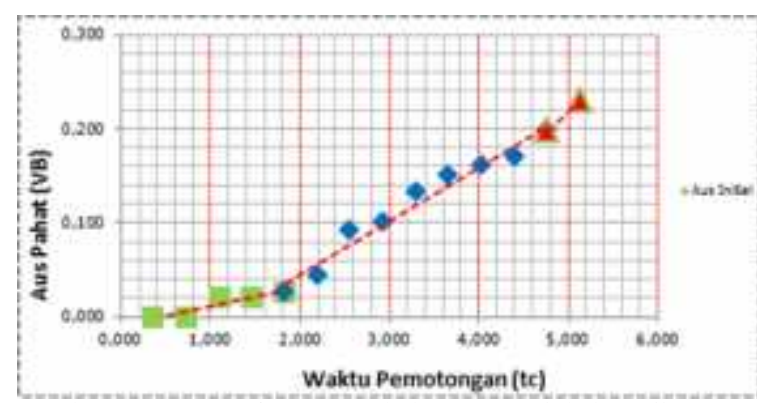

Gambar 22. Kurva 3 fasa pertumbuhan Aus tepi, bahan uji AISI1070 Kondisi: $V=70 \mathrm{~m} / \mathrm{min} ; \mathrm{f}=0.15 \mathrm{~mm} / \mathrm{rad} ; \mathrm{a}=1.5$ $\mathrm{mm}$

Analisa pertumbuhan telah terjadi Aus mekanik pada pahat berupa Aus tepi akibat tidak konsistennya tekana potong yang terjadi, yaitu besarnya kedalaman potong (a) dan besarnya pemakanan (f) pada proses pemesinan menggunakan bahan uji Baja AISI-1070 yang memiliki kekerasan 93.3 HRB. Disimpulkan Aus tepi yang terjadi berada pada batas yang diizinkan yaitu: $\mathrm{V}_{\mathrm{B}}>0.3 \mathrm{~mm}$ (dibawah batas $\mathrm{V}_{\mathrm{Bmax}}$ ), dalam waktu tidak kurang dari $\mathrm{t}_{\mathrm{c}}=5.00 \mathrm{~min}$, [18].

\section{Pahat Karbida Berlapis Diamond-Film Uji Pengaruh Beban Mekanik}

Tabel 8. Hasil uji pahat karbida berlapis diamond-film pemesinan

\begin{tabular}{|c|c|c|c|c|c|c|c|}
\hline$\underset{(\mathbf{m} / \mathbf{m i n})}{\mathbf{V}}$ & $\begin{array}{c}\mathbf{f} \\
(\mathbf{m m} / \mathbf{r} \\
\mathbf{a d})\end{array}$ & $\begin{array}{l}\text { a } \\
(\mathbf{m} \\
\mathrm{m})\end{array}$ & $\underset{(\mathbf{m m})}{\mathbf{d}}$ & $\begin{array}{c}\mathbf{n} \\
(\mathbf{r p m} \\
)\end{array}$ & $\begin{array}{l}\text { It } \\
(\mathbf{m} \\
\mathbf{m})\end{array}$ & $\underset{(\mathbf{m i n})}{\begin{array}{c}\mathbf{t}_{\mathrm{c}} \\
\text { (n) }\end{array}}$ & $\begin{array}{c}\text { VB } \\
(\mathbf{m m})\end{array}$ \\
\hline 350 & 0.15 & 1.5 & 132 & 845 & 55 & 0.434 & 0.000 \\
\hline 350 & 0.15 & 1.5 & 132 & 845 & 110 & 0.868 & 0.035 \\
\hline 350 & 0.15 & 1.5 & 132 & 845 & 165 & 1.302 & 0.051 \\
\hline 350 & 0.15 & 1.5 & 132 & 845 & 220 & 1.736 & 0.096 \\
\hline 350 & 0.15 & 1.5 & 132 & 845 & 275 & 2.170 & 0.164 \\
\hline 350 & 0.15 & 1.5 & 132 & 845 & 330 & 2.604 & 0.194 \\
\hline 350 & 0.15 & 1.5 & 132 & 845 & 385 & 3.037 & 0.229 \\
\hline 350 & 0.15 & 1.5 & 132 & 845 & 440 & 3.471 & 0.254 \\
\hline 350 & 0.15 & 1.5 & 132 & 845 & 495 & 3.905 & 0.269 \\
\hline 350 & 0.15 & 1.5 & 132 & 845 & 550 & 4.339 & 0.284 \\
\hline 350 & 0.15 & 1.5 & 132 & 845 & 605 & 4.773 & 0.313 \\
\hline 350 & 0.15 & 1.5 & 132 & 845 & 660 & 5.207 & 0.420 \\
\hline
\end{tabular}

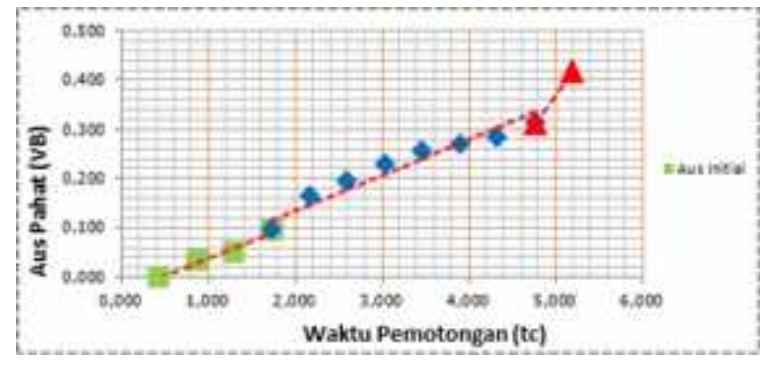

Gambar 23. Kurva pertumbuhan Aus tepi pahat,bahan uji Al-6061 Kondisi: $\mathrm{V}=350 \mathrm{~m} / \mathrm{min} ; \mathrm{f}=0.15 \mathrm{~mm} / \mathrm{rad} ; \mathrm{a}=1.5 \mathrm{~mm}$; $\mathrm{t}_{\mathrm{c}}=5.207$ min dan $\mathrm{V}_{\mathrm{B}}=0.420 \mathrm{~mm}$.

Tabel 9. Hasil uji pahat berlapis diamond film, bahan uji Al-6061 fasa Initial-wear

\begin{tabular}{rcccccccc}
\hline $\begin{array}{c}\mathbf{V} \\
(\mathbf{m} / \mathbf{m i n})\end{array}$ & $\begin{array}{c}c \\
(\mathbf{m m} / \mathbf{r} \\
\mathbf{a d})\end{array}$ & $\begin{array}{c}\mathbf{a} \\
(\mathbf{m m})\end{array}$ & $\begin{array}{c}\mathbf{d} \\
(\mathbf{m m})\end{array}$ & $\begin{array}{c}\mathbf{n} \\
(\mathbf{r p m}\end{array}$ & $\begin{array}{c}\mathbf{l t} \\
(\mathbf{m m})\end{array}$ & $\begin{array}{c}\mathbf{t}_{\mathbf{c}} \\
(\mathbf{m i n})\end{array}$ & $\begin{array}{c}\mathbf{V B} \\
(\mathbf{m m})\end{array}$ \\
\hline 350 & 0.15 & 1.5 & 132 & 845 & 220 & 1.736 & 0.070 \\
\hline
\end{tabular}




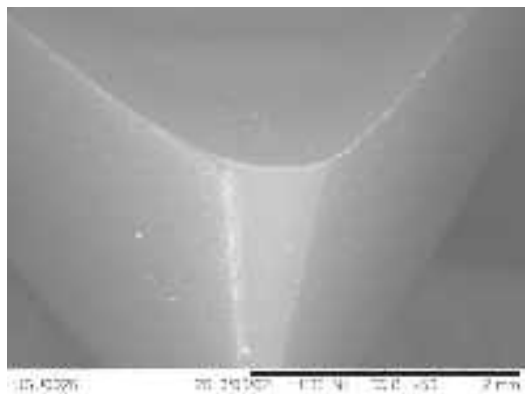

Gambar 24. Penampang pahat karbida berlapis diamond film original.

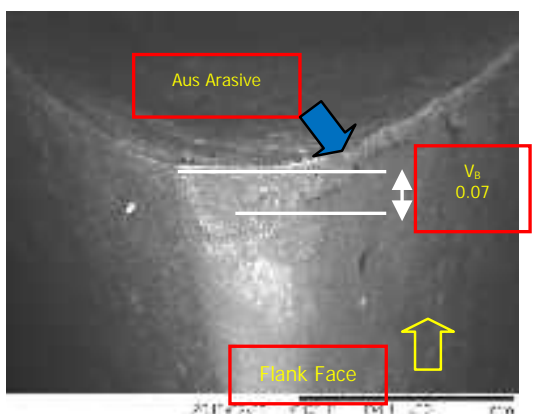

Gambar 25. Aus abrasive (initial-wear) pahat karbida berlapis diamond film bahan uji Al-6061. Kondisi: $\mathrm{V}=350$ $\mathrm{m} / \mathrm{min}\left|\mathrm{t}_{\mathrm{c}}=1.736 \mathrm{~min} ; 104.160 \mathrm{dtk}\right| \mathrm{V}_{\mathrm{B}}=0.070 \mathrm{~mm} ; \mathrm{V}_{\mathrm{B}}{ }^{\circ}=$ $0.000672 \mathrm{~mm} / \mathrm{dtk}$

Gambar 24 adalah pahat karbida berlapis diamond film original dengan komposisi material inti (substrate) $\mathrm{WC}=94 \%$ dan $\mathrm{Co}=6 \%$ dan material pelapis tungggal diamond-film single layer $(6 \mu \mathrm{m})$. Pahat ini di desain khusus untuk pemesinan bubut dengan data rekomendasi pemotongan yaitu mampu melakukan pemotongan kecepatan (V) hingga 2000 $\mathrm{m} /$ min dengan kedalaman potong (a) hingga $1.5 \mathrm{~mm}$ dan pemakanan (f) hingga $0.20 \mathrm{~mm} / \mathrm{rad}$.

Sebagaimana diperlihatkan pada Gambar 25, besar pertumbuhan Aus pada tepi yaitu: $\mathrm{V}_{\mathrm{B}}=0.070$ $\mathrm{mm}$ dengan percepatan aus rata-rata $\mathrm{V}_{\mathrm{B}}{ }^{\circ}=0.000672$ $\mathrm{mm} / \mathrm{dtk}$ yang terjadi terhadap pahat pada fasa Initialwear $t_{c}=1.736$ min. Secara rinci bentuk kegagalan yang terjadi pada mata potong pahat ditetapkan sebagai Aus pengikisan (abrasive-wear), dimana besaran Aus pengikisan diukur dari puncak muka sadak mata pahat (rake face) terhadap batas bawah terjadinya Aus (wear). Terhadap besar Aus abrasive yang terjadi masih dalam batas dibawah $\mathrm{V}_{\mathrm{B}} \max \left(\mathrm{V}_{\mathrm{B}}\right)$ $0.3 \mathrm{~mm}$ ). Maka hasil penelitian terhadap pengaruh beban mekanik dapat diartikan bahwasanya pada penggunaan bahan uji Aluminium 6061 (non-ferro metal) mengindikasikan bahwa keadaan yaitu tidak dijumpai kegagalan pahat dalam wujud pengelupas lapisan/pelapis pahat terhadap material substrate. Percepatan pertumbuhan Aus pahat rata-rata $\left(\mathrm{V}_{\mathrm{B}}{ }^{\circ}\right)$ pada fasa Initial-wear bahan uji Al-6061 dijelaskan pada Tabel 10.

Tabel 10. Hasil uji pahat karbida berlapis diamond film pemesinan bahan AISI-1070

\begin{tabular}{ccccccccc}
\hline $\begin{array}{c}\mathbf{V} \\
(\mathbf{m} / \mathbf{m i n})\end{array}$ & $\begin{array}{c}\mathbf{f} \\
(\mathbf{m m} / \mathbf{r} \\
\mathbf{a d})\end{array}$ & $\begin{array}{c}\mathbf{a} \\
(\mathbf{m m})\end{array}$ & $\begin{array}{c}\mathbf{d} \\
(\mathbf{m}) \\
\mathbf{m})\end{array}$ & $\begin{array}{c}\mathbf{n} \\
(\mathbf{r p m}\end{array}$ & $\begin{array}{c}\mathbf{l t} \\
(\mathbf{m m} \\
)\end{array}$ & $\begin{array}{c}\mathbf{t}_{\mathbf{c}} \\
(\mathbf{m i n})\end{array}$ & $\begin{array}{c}\mathbf{V B} \\
(\mathbf{m m})\end{array}$ \\
\hline 70 & 0.15 & 1.5 & 41 & 545 & 30 & 0.367 & 0.141 \\
70 & 0.15 & 1.5 & 41 & 545 & 60 & 0.734 & 0.250 \\
70 & 0.15 & 1.5 & 41 & 545 & 90 & 1.101 & 0.261 \\
70 & 0.15 & 1.5 & 41 & 545 & 120 & 1.468 & 0.294 \\
70 & 0.15 & 1.5 & 41 & 545 & 150 & 1.835 & 0.311 \\
70 & 0.15 & 1.5 & 41 & 545 & 180 & 2.202 & 0.326 \\
70 & 0.15 & 1.5 & 41 & 545 & 210 & 2.569 & 0.390 \\
\hline
\end{tabular}

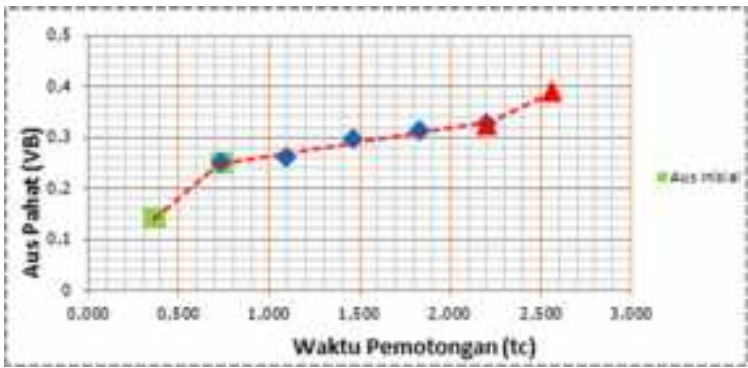

Gambar 26. Kurva pertumbuhan Aus tepi pahat pemesinan bahan uji AISI-1070 Kondisi: $\mathrm{V}=70 \mathrm{~m} / \mathrm{min} ; \mathrm{f}=0.15$ $\mathrm{mm} / \mathrm{rad} ; \mathrm{a}=1.5 \mathrm{~mm} ; \mathrm{t}_{\mathrm{c}}=2.569 \mathrm{~min}$ dan $\mathrm{V}_{\mathrm{B}}=0.390$ $\mathrm{mm}$.

Tabel 11. Hasil uji pahat berlapis diamond film, bahan uji AISI1070 fasa Initial-wear

\begin{tabular}{|c|c|c|c|c|c|c|c|}
\hline$\underset{(\mathbf{m} / \mathbf{m i n})}{\mathbf{V}}$ & $\begin{array}{c}\mathbf{f} \\
(\mathbf{m m} / \mathbf{r} \\
\mathbf{a d})\end{array}$ & $\begin{array}{c}\mathbf{a} \\
(\mathrm{mm} \\
)\end{array}$ & $\underset{(\mathbf{m m})}{\mathbf{d}}$ & $\begin{array}{c}\mathbf{n} \\
(\mathbf{r p} \\
\mathbf{m}) \\
\end{array}$ & $\underset{(\mathbf{m m})}{\mathbf{l t}}$ & $\underset{(\mathbf{m i n})}{\begin{array}{c}\mathbf{t}_{\mathrm{c}} \\
\text { (n) }\end{array}}$ & $\begin{array}{l}\text { VB } \\
(\mathbf{m m})\end{array}$ \\
\hline 70 & 0.15 & 1.5 & 41 & 545 & 60 & 0.734 & 0.250 \\
\hline
\end{tabular}

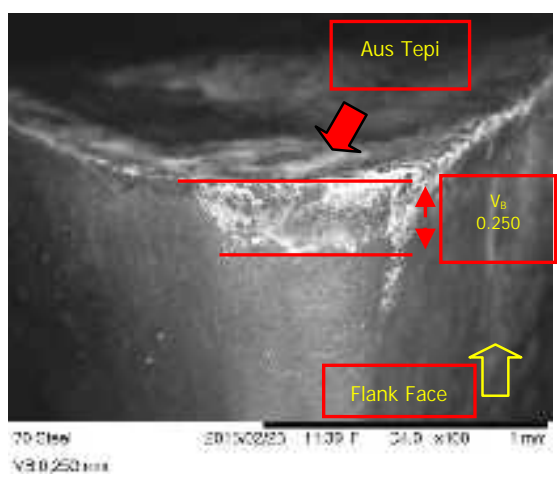

Gambar 27. Aus tepi (initial-wear) pahat karbida berlapis diamond film pemesinan bahan uji AISI-1070. Kondisi: $V=70$ $\mathrm{m} / \mathrm{min}\left|\mathrm{t}_{\mathrm{c}}=0.734 \mathrm{~min} ; 44.040 \mathrm{dtk}\right| \mathrm{V}_{\mathrm{B}}=0.250 \mathrm{~mm} ; \mathrm{V}_{\mathrm{B}}{ }^{\circ}=$ $0.005677 \mathrm{~mm} / \mathrm{dtk}$

Hasil penelitian yang ditunjukkan pada Tabel 11, terhadap analisa didapati pertumbuhan Aus tepi sebesar $\mathrm{V}_{\mathrm{B}}=0.250 \mathrm{~mm}$ dengan percepatan Aus ratarata $\mathrm{V}_{\mathrm{B}}{ }^{\circ}=0.005677 \mathrm{~mm} / \mathrm{dtk}$ yang terjadi pada fasa Initial-wear dengan waktu pemotongan $\mathrm{t}_{\mathrm{c}}=0.734$ min. Efek dominan terhadap cepatnya pertumbuhan Aus tepi yang terjadi disinyair terutama terhadap kekerasan bahan uji, besarnya kedalaman potong (a) dan besarnya pemakanan (f) yang diaplikasikan. 
Sebagaimana diperlihatkan pada Gambar 27. Aus tepi mencolok yang terjadi disebabkan hilangnya sebagian dari volume material terluar ujung mata pahat, sehingga dikhawatirkan menyebabkan penurunan intim kontak pahat terhadap bahan uji untuk aplikasi waktu pemotongan yang lebih lama lagi. Percepatan pertumbuhan Aus pahat rata-rata $\left(\mathrm{V}_{\mathrm{B}}{ }^{\circ}\right)$ pada initial-wear bahan uji Baja AISI-1070 dijelaskan pada Tabel 12.

Uji Pengaruh Reaksi Kimiawi

Analisa lapisan diamond-film pahat pada bahan uji Al-6061 AlMg1SiCu

Tabel 12. Distribusi besaran unsur lapisan diamond-film pada

\begin{tabular}{|c|c|c|c|}
\hline Element & $\begin{array}{l}\text { Weight } \\
\%\end{array}$ & Atomic \% & Keterangan \\
\hline \multicolumn{4}{|c|}{ Spectrum-1 } \\
\hline $\begin{array}{l}\text { Carbon } \\
\text { Cobalt } \\
\text { Tungsten }\end{array}$ & $\begin{array}{l}99.113 \\
0.626 \\
0.260\end{array}$ & $\begin{array}{l}99.854 \\
0.129 \\
0.017\end{array}$ & $\begin{array}{l}\text { Unsur lapisan/pelapis } \\
\text { (diamond film) } \\
\text { signifikan }\end{array}$ \\
\hline \multicolumn{4}{|c|}{ Spectrum-2 } \\
\hline $\begin{array}{l}\text { Carbon } \\
\text { Tungsten }\end{array}$ & $\begin{array}{l}99.947 \\
0.260\end{array}$ & $\begin{array}{l}99.997 \\
0.003\end{array}$ & $\begin{array}{l}\text { Unsur lapisan/pelapis } \\
\text { (diamond film) } \\
\text { signifikan }\end{array}$ \\
\hline
\end{tabular}

Pada Gambar 28 dan Tabel 12, pada spectrum-1 (flank wear), hasil dari analisa energy dispersive spectroscopy (EDS) didapati besar sebaran unsur pelapis diamond-film (carbon) terdeteksi signifikan mencapai $99.854 \%$ atomic, sementara unsur lainnya yaitu Cobalt (Co) dan Tungsten (W) besaran unsur yang terdeteksi kurang dari $0.02 \%$ atomic, sehingga dapat diartikan bahwasanya pada daerah kritis terjadinya kegagalan pahat (abrasive-wear) diketahui adalah unsur pelapis diamond-film yang masih berwujud keadaanya dan masih konsisten melapisi material substrate pahat atau dapat diartikan pada daerah analisa spectrum-1 (flank wear) tidak terlihat adanya indikasi telah terjadi pengelupasan lapisan pahat terhadap material substrate diamond-film pahat. Pada hasil analisa reaksi kimiawi membuktikan bahwa sifat dari bahan pelapis diamond-film (carbon) yaitu sifat kekerasan tinggi meyebabkan tidak signifikan terpengaruh akibat beban mekanik saat memotong material non-ferro metal (Aluminium $6061 \mathrm{AlMg} 1 \mathrm{SiCu}$ ) yang memiliki sifat kekerasan rendah.

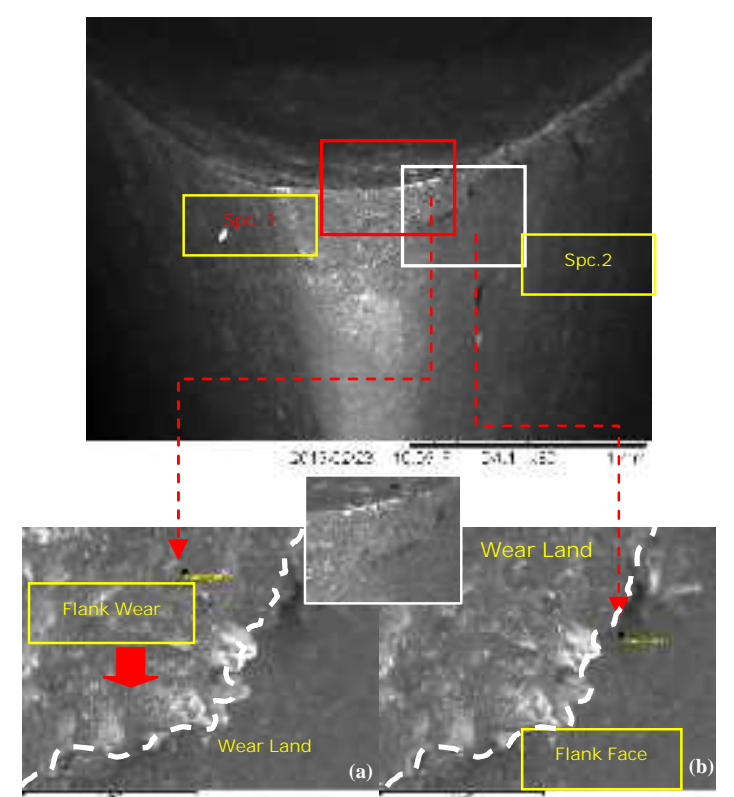

Gambar 28. Daerah analisa: [a] Spec -1; [b] Spec -2, Penyelidikan unsur lapisan pahat bahan uji Al-6061. Kondisi $\mathrm{V}=350 \mathrm{~m} / \mathrm{min} \mid \mathrm{f}=$ $0.15 \mathrm{~mm} / \mathrm{rad}|\mathrm{a}=1.5 \mathrm{~mm}| \mathrm{t}_{\mathrm{c}}=1.736 \mathrm{~min} ; 104.160 \mathrm{dtk} \mid \mathrm{V}_{\mathrm{B}}=0.070$ $\mathrm{mm}$.

Sementara itu, pada Gambar 30 dan Tabel 13 Spectrum-2 (flank face), dapat diuraikan hasil dari analisa energy dispersive spectroscopy (EDS) menunjukkan besar sebaran unsur pelapis diamondfilm (carbon) terdeteksi signifikan dan utuh hingga mencapai prosentase $99.997 \%$ atomic, sementara unsur lainnya yaitu Tungsten (W) besaran unsur yang terdeteksi sangat tidak signifikan karena jumlah besaran unsurnya tidak lebih dari $0.003 \%$ atomic, sehingga dapat diartikan bahwa daerah analisa pada spectrum-2 (flank face) adalah material unsur pelapis diamond-film sepenuhnya dan tidak terpengaruh oleh unsur-unsur lainnya yang merusak struktur lapisan dimond-film pahat.

Tabel 13. Distribusi besaran unsur lapisan diamond-film pada $\mathrm{V}=$ $70 \mathrm{~m} / \mathrm{min}$

\begin{tabular}{|c|c|c|c|}
\hline Element & Weight \% & Atomic \% & Keterangan \\
\hline \multicolumn{4}{|c|}{ Spectrum-1 } \\
\hline $\begin{array}{l}\text { Carbon } \\
\text { Fluorine } \\
\text { Chromium } \\
\text { Cobalt } \\
\text { Tungsten } \\
\end{array}$ & $\begin{array}{l}34.623 \\
6.878 \\
44.181 \\
8.130 \\
6.189 \\
\end{array}$ & $\begin{array}{l}67.573 \\
8.486 \\
19.918 \\
3.234 \\
0.789 \\
\end{array}$ & $\begin{array}{l}\text { Unsur lapisan/pelapis } \\
\text { (diamond-film) signifikan }\end{array}$ \\
\hline \multicolumn{4}{|c|}{ Spectrum-2 } \\
\hline $\begin{array}{l}\text { Carbon } \\
\text { Cobalt } \\
\text { Tungsten }\end{array}$ & $\begin{array}{l}79.547 \\
16.175 \\
4.277\end{array}$ & $\begin{array}{l}95.698 \\
3.966 \\
0.336\end{array}$ & $\begin{array}{l}\text { Unsur lapisan/pelapis } \\
\text { (diamond-film) signifikan }\end{array}$ \\
\hline
\end{tabular}




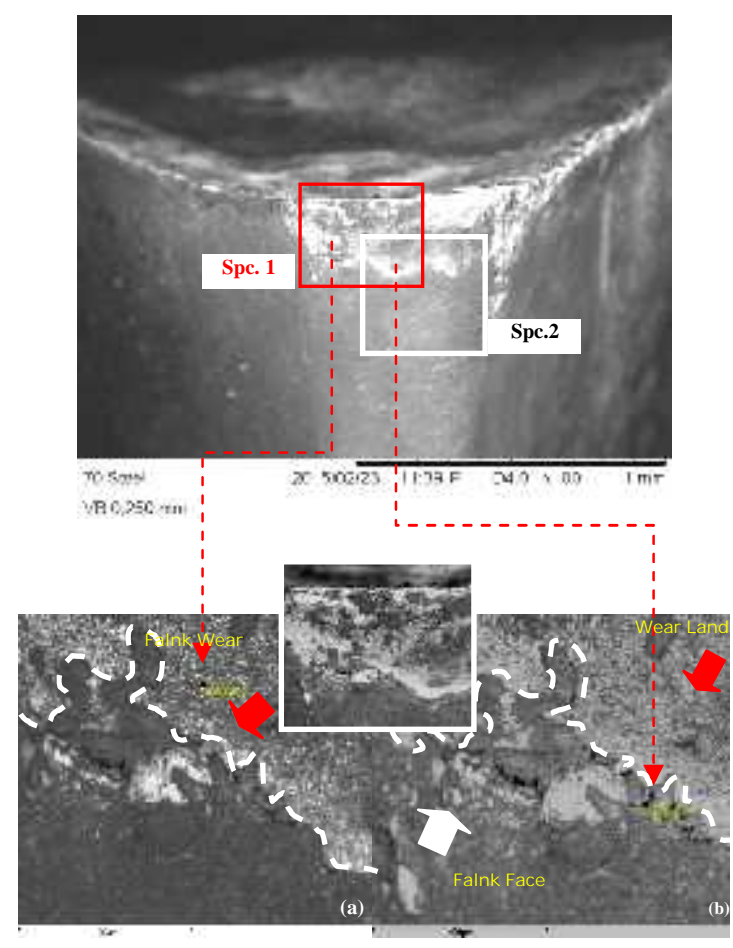

Gambar 30. Daerah analisa pahat: [a] Spectrum-1; [b] Spectrum-2, Penyelidikan unsur lapisan pahat bahan uji AISI1070. Kondisi $\mathrm{V}=70 \mathrm{~m} / \mathrm{min}|\mathrm{f}=0.15 \mathrm{~mm} / \mathrm{rad}| \mathrm{a}=$ $1.5 \mathrm{~mm}\left|\mathrm{t}_{\mathrm{c}}=0.734 \mathrm{~min} ; 44.040 \mathrm{dtk}\right| \mathrm{V}_{\mathrm{B}}=0.250 \mathrm{~mm}$.

Apabila diamati hasil dari analisa energy dispersive spectroscopy (EDS) terhadap distribusi sebaran unsur-unsur pada pada Gambar 30 dan Tabel 13. spctrum-1, menjustifikasi bahwa unsur Carbon (C) sebagai unsur tunggal material pelapis diamondfilm sudah tidak konsisten lagi berada pada prosentase $100 \%$ atomic, dikarenakan nilai unsur pelapis diamond-film (carbon) yang terdeteksi pada daerah spectrum-1 hanya pada besaran $67.573 \%$ atomic, dan sudah tergantikan oleh sebaran unsurunsur lain diantaranya yaitu: Flourine (F), Choromium (Cr), Kobalt (Co) dan Tungsten (W). Unsur material lain tersebut merupakan unsur-unsur dari material substrate (WC/Co) dan sebagian lainnya terdeteksi marupakan unsur-unsur material bahan uji yang terdifusi pada lapisan diamond-film. Diantara unsur lain selain dari unsur lapisan dimond-film (carbon), terdeteksi signifikan yaitu unsur Choromium (Cr) yang merupakan unsur yang terdapat pada bahan AISI-1070 dan prosentase besaran sebaran unsur mencapai $19.918 \%$ atomic.

Pada pengamatan menggunakan analisa scanning electron microscope (SEM), yang kemudian diperkaya dengan analisa energy dispersive spectroscopy (EDS), maka dari fonomena distribusi sebaran unsur yang terjadi pada daerah analisa spectrum-1, dipastikan telah terjadin Aus pengikisan lapisan (abrasive-coating wear) pada lapisan diamond-film yang melapisi material substrate pahat, dikarenakan keberadaan unsur lapisan diamond-film pahat sudah tidak berwujud sempurna lagi. Terjadinya Aus pengikisan lapisan (abrasive coatingwear) pada lapisan diamond-film pahat disinyalir terjadi pengaruh yang akibat dari peristiwa Aus mekanis yang terjadi pada fasa Initial-wear yaitu: $t_{c}=$ $0.734 \mathrm{~min} ; 44.040 \mathrm{dtk}$, saat pembubutan kering berlangsung. Hal ini menandakan sifat utama dari unsur pelapis diamond-film (carbon) yaitu keras namun rapuh (britell) yang menyebabkan terjadinya Aus pengikisan lapisan (abrasive coating wear) pada lapisan pahat pada daerah kontak.

Sementara itu, pada Gambar 30 dan Tabel 13, hasil dari analisa energy dispersive spectroscopy (EDS) pada spectrum-2, menjelaskan besar sebaran unsur pelapis diamond-film (carbon) terdeteksi signifikan hingga mencapai $95.698 \%$ atomic, sementara unsur lainnya yang terdeteksi tidak signifikan adalah unsur Cobalt (Co) dan Tungsten (WC) dengan besaran prosentase unsur yang terdeteksi kurang dari 5\%. Maka dapat diartikan bahwasanya pada daerah kritis/zona terjadinya kegagalan pahat yang dianalisa pada daerah spectrum-2 diketahui adalah material unsur pelapis diamond-film (carbon) yang keadaanya masih berwujud signifikan. Pada hasil penyelidikan terhadap peningkatan kecepatan potong yang diaplikasikan dalam penelitian, disimpulkan tidak terjadi pengelupasan lapisan seperti hasil penelitian yang telah dilaporkan oleh [7], yaitu peningkatan kecepatan potong mempunyai pengaruh signifikan terhadap kegagalan lapisan pahat karbida berlapis.

\section{Karakterisasi Lapisan Diamond-Film Pahat Karbida}

Terhadap keseluruhan data penelitian melalui pendekatan beban Mekanik, beban Thermal dan interaksi secara Kimiawi yang terjadi antara bahan benda kerja dan pahat yang dihasilkan, dapat mengindikasikan karakteristik lapisan diamond-film CVD pahat karbida setelah mengalami perlakuan, maka dianalisa keseluruhan aspek pendekatan yang dilakukan untuk menjawab dari tujuan khusus yang diinginkan.

Pada analisa aspek pengaruh beban Mekanik, pada pemesinan bahan uji Aluminium Paduan 6061 $\mathrm{AlMg} 1 \mathrm{SiCu}$ (non-ferro metal) dengan kekerasan bahan uji sebesar 53.3 HRB/95 HV. Rekomendasi hasil penelitian pada kondisi pemotongan yang dilaksanakan mengindikasikan performa 
lapisan/pelapis diamond-film masih dalam keadaan yang sangat baik. Hal yang tidak sejalan dialami oleh lapisan/pelapis pahat untuk pemotongan bahan uji Baja paduan AISI-1070 (ferro metal) dengan kekerasan bahan sebesar 93.3 HRB/200 HV. Dimana indikasi yang ditemukan terhadap kondisi lapisan/pelapis diamond-film CVD yaitu telah berkurangnya secara signifikan volume unsur material pelapis diamond-film disebabkan telah terjadinya Aus pengikisan lapisan (abrasive-coating wear) akibat dari peristiwa Aus mekanis saat dilakukan proses bubut kering pada bahan uji yang tingkat kekerasan bahan yang lebih tinggi.

Analisa terhadap aspek pengaruh beban Thermal, indikasi terhadap data hasil penelitian pada operasi bubut kering bahan uji Aluminium Paduan 6061 $\mathrm{AlMg} 1 \mathrm{SiCu}$. Melalui peningkatan kecepatan potong sebesar 22\%, dengan demikian temperatur pemotongan juga akan turut serta semakin tinggi terjadi pada daerah kontak antara pahat terhadap bahan uji. Pada analisa hasil peningkatan beban thermal, indikasi terjadinya pengelupasan pelapis/lapisan diamond-fim tidak ditemukan sama sekali, dengan demikian dapat direkomendasikan untuk pemesinan bahan Aluminium paduan 6061 $\mathrm{AlMg} 1 \mathrm{SiCu}$ terhadap kondisi pemotongan yang dilaksanakan. Kemudian pada perubahan kecepatan potong sebesar 22\% terhadap bahan uji Baja paduan AISI 1070, peristiwa kegagalan lapisan diamond-film CVD juga tidak ditemukan.

Perihal yang telah ditemukan yaitu telah terjadi Aus pengikisan lapisan (abrasive coating-wear) pada lapisan/pelapis pahat. Peristiwa terjadinya Aus pengikisan lapisan (abrasive coating wear) pada kecepatan potong yang rendah (temperatur rendah) dikerenakan unsur material ferro $(\mathrm{Fe})$ belum bereaksi terhadap unsur substrate pahat (WC/Co) sehingga tidak menyebabkan reaksi kimia yang menghasilkan karbon, karena ferro (Fe) tidak akan bereaksi dengan lapisan diamond-film (carbon) pahat. Sementara itu, peristiwa Aus pengikisan lapisan (abrasive coatingwear) pada peningkatan kecepatan potong (temperatur tinggi), adalah pengaruh unsur material ferro $(\mathrm{Fe})$ yang bereaksi terhadap unsur substrate pahat (WC/Co) sehingga menyebabkan reaksi kimia yang menghasilkan karbon hasil pembakaran (thermal), karena ferro ( $\mathrm{Fe})$ akan bereaksi dengan unsur Tungsten (WC) dan unsur Cobalt (Co) material substrate pada temperatur tinggi. Dengan demikian pada pengaruh terhadap perubahan temperatur pemotongan, tidak signifikan terhadap kecenderungan perubahan karakteristik lapisan/pelapis pahat yaitu berupa kegagalan lapisan/pelapis diamond-film CVD. Dengan demikian terhadap hasil penelitian yang ditemukan, tidak sejalan seperti yang dilaporkan oleh [27], bahwa peningkatan kecepatan potong untuk pengerjaan bahan uji Aluminium paduan dan Baja paduan maka akan berpengaruh terhadap peningkatan temperatur pemotongan, dan memiliki pengaruh yang sangat reaktif terhadap kegagalan lapisan/pelapis pahat karbida berlapis.

Analisa terhadap aspek pengaruh interaksi secara Kimiawi yang terjadi antara bahan benda kerja dan bahan pahat melalui data dan informasi yang dihasilkan. Untuk bahan uji Aluminium paduan 6061 $\mathrm{AlMg} 1 \mathrm{SiCu}$ melalui micro analysis (EDS), diperoleh indikasi kondisi unsur pelapis diamond-film masih berwujud atau dengan kata lain kondisi unsur material pelapis yang melapisi material substrate pahat tidak mengalami pengelupasan lapisan (coating delamination) sebagaimana laporan hasil penelitian yang diungkapkan oleh peneliti [6], yang dalam laporannya menyimpulkan bahwa terjadi pengelupasan lapisan (coating delamination) yaitu lapisan-lapisan dari bahan pelapis yang digunakan untuk melapisi dari material inti (substrate) pahat karbida terkelupas pada saat proses pemotongan logam non-ferro berlangsung, dan lapisan tersebut terkelupas pada saat awal proses pemotongan atau pada saat awal terjadinya aus (initial-wear), yang kemudian diperkaya oleh hasil penelitian [7], yang melaporkan penggunaan pahat karbida berlapis pada operasi bubut bahan non-ferro metal, mendapati kegagalan lapisan pahat karbida berlapis (NCD) dan kecepatan potong memiliki pengaruh dominan pada kegagalan lapisan.

Selanjutnya, melalui micro analysis (EDS) terhadap performa lapisan/pelpais diamond-film pada bahan uji Baja AISI 1070, diperoleh sebaran unsur pelapis (diamond-film) masih konsisten melapisi material substrate pahat, hal tersebut mengindikasikan pada kenyataan tidak terjadinya pengelupasan lapisan diamond-film yang melapisi material substrate pahat terhadap hasil pemesinan kering, melainkan peristiwa yang ditemukan terhadap kondisi lapisan/pelapis diamond film yaitu kegagalan pahat yang terjadi dalam bentuk Aus pengikisan lapisan (abrasive coating-wear). Peristiwa terjadinya Aus pengikisan lapisan yang terjadi pada material Baja AISI 1070 diketahui adalah penguruh terjadi Aus mekanis akibat faktor.

\section{Kesimpulan}


Hasil penelitian yang diperoleh dari pengujian pada pendekatan pengaruh beban Mekanik, beban Thermal dan interaksi secara Kimiawi yang terjadi antara bahan benda kerja dan pahat merupakan jawaban dari tujuan khusus, dimana hasil analisa terhadap pengujian tersebut dapat disimpulkan sebagai berikut:

1. Pengujian pengaruh beban Mekanik

a. Hasil pengujian menggunakan bahan uji

Aluminium $6061 \quad \mathrm{AlMg} 1 \mathrm{SiCu}, \quad$ kondisi pemotongan: $\mathrm{v}=350 \mathrm{~m} / \mathrm{min}, \mathrm{f}=0.15 \mathrm{~mm} /$ put dan $\mathrm{a}=$ $1.5 \mathrm{~mm}$, fasa Initial-wear $\mathrm{t}_{\mathrm{c}}=1.736 \mathrm{~min}$, diperoleh keadaan sebagai berikut:

Kegagalan lapisan diamond-film CVD pahat karbida tidak ditemukan pada operasi bubut kering bahan uji dengan tingkat kekerasan 53.3 HRB/95 HV. Kegagalan pahat yang terjadi yaitu ditemukan Aus pengikisan (abrasive-wear) sebesar $V_{B}=0.07$ $\mathrm{mm}$, percepatan Aus rata-rata $\mathrm{V}_{\mathrm{B}}{ }^{\circ}=0.000672 \mathrm{~mm} / \mathrm{s}$. Hasil analisa distribusi besaran sebaran unsur pelapis (diamond-film) yang dianalisa pada spec-1 terdeteksi signifikan mencapai $99.854 \%$ dan pada spec-2 menunjukkan besaran sebaran unsur terdeteksi signifikan dan utuh hingga mencapai prosentase 99.997\%, Dikarenakan melalui hasil identifikasi distribusi unsur pada titik analisa pada spec-1 dan spec-2 diketahui adalah material unsur pelapis diamond-film yang masih berwujud utuh keadaanya dan masih konsisten melapisi material substrate, maka dismpulkan tidak adanya indikasi telah terjadi pengelupasan lapisan/pelapis pahat terhadap material substrate diamond-film pahat.

b. Hasil pengujian menggunakan bahan uji AISI 1070, kondisi pemotongan: $\mathrm{v}=70 \mathrm{~m} / \mathrm{min}, \mathrm{f}=0.15$ $\mathrm{mm} /$ put dan $\mathrm{a}=1.5 \mathrm{~mm}$, fasa Initial-wear $\mathrm{t}_{\mathrm{c}}=0.734$ min, diperoleh keadaan sebagai berikut:

Kegagalan lapisan diamond-film CVD pahat karbida tidak ditemukan pada operasi bubut kering bahan uji dengan tingkat kekerasan 93.3 HRB/200 HV. Hasil analisa yang didapati yaitu pertumbuhan Aus tepi sebesar $\mathrm{V}_{\mathrm{B}}=0.250 \mathrm{~mm}$, percepatan aus ratarata $\mathrm{V}_{\mathrm{B}}{ }^{\circ}=0.005677 \mathrm{~mm} / \mathrm{s}$. Hasil penelitian diinformasikan bahwasanya fonomena distribusi sebaran unsur yang terjadi pada daerah analisa spec-1 menjustifikasi sudah hilangnya sebahagian volume pelapis diamond-film yang melapisi material substrate, dikarenakan keberadaan unsur lapisan diamond-film (carbon) pahat sudah tidak berwujud sempurna yaitu dengan prosentase hanya sebesar $67.573 \%$. Sementara itu pada spec-2 didapati besar sebaran unsur pelapis diamond-film (carbon) terdeteksi sangat signifikan hingga mencapai $95.698 \%$. Jika diamati fonomena sebaran unsur yang terjadi pada spectrum-1 dan spectrum-2 pada titik analisa disimpulkan juga tidak terjadi peristiwa pengelupasan lapisan/pelapis (coating delamination) dimond-film pahat, melainkan telah terjadi Aus pengikisan lapisan (abrasive coating wear) dikarenakan prosentase jumlah unsur material pelapis diamond-film telah berkurang hingga lebih dari 30 $\%$, dengan kata lain keberadaan unsur lapisan/pelapis diamond-film pahat sudah tidak berwujud sempurna lagi. Sebab terjadinya peristiwa Aus pengikisan lapisan (abrasive coating wear) pada peningkatan kecepatan potong (temperatur tinggi), adalah pengaruh unsur material ferro $(\mathrm{Fe})$ akan bereaksi terhadap unsur substrate pahat (WC/Co) sehingga menyebabkan reaksi kimia yang menghasilkan karbon hasil pembakaran, karena ferro (Fe) akan bereaksi dengan unsur Tungsten (WC) dan unsur Cobalt (Co) material substrate pada temperatur tinggi.

\section{Daftar Pustaka}

[1] Jhon A.Schey, Proses Manufaktur "Introduction to Manufaktur Processes" Edisi ketiga" (2009).

[2] Armansyah Ginting, Analisa Pembentukan Serpihan Tehadap Kegagalan dan Mekanisme Aus Pahat Karbida pada pembubutan kering Aluminium 6061T6. (2004).

[3] Sreejith, and Ngoi, B.K.A. Dry machining, machining of the future. J,(2000).

[4] Schulz, E. Abele, A. Sahm, Material aspects of chip formation in HSC machining, Ann. CIRP 50 (1) (2001) 45-48.

[5] M. Fitzsimmons, V.K. Sarin, Surf. Coat. Technol, (2001) 158.

[6] M. Nouari, A. Ginting. Wear characteristics and performance of multi-layerCVD-coated alloyed carbide tool in dry end milling of titanium alloy, (2006).

[7] J. Hu a, Y.K. Chou, R.G. Thompson. Nanocrystalline diamond coating tools for machining high strength $\mathrm{Al}$ alloys, (2008).

[8] Armansyah Ginting, High Speed Machining of AISI 01 Steel With Multilayer Ceramic CVD-Coated carbide; Tool Life and Surface Integrity, Vol 14, No. 3, Agustus 2003- majalah IPTEK, (2003).

[9] Seco. Dry Machining, (2004).

[10] Abdeel-Aal, H.M., Nouari, M., El-Mansori, M. and Ginting, A. 2006. Conceptual triboenergetic analysis of cutting tool protective coating delamination in dry cutting of hard-tocut engine alloys. Submitted to Int. J. Adv. Manuf. Technol.

[11] U.Prabhu Arumugam, Ajay P Malshe, Stephen A Batzer, Deepak G Bhat Study of Airbone Dust Emissionand Orocess Performance During Dry Machining of Aluminum-Silicon Alloy with PCD and CVD

[12] Boothroyd, G., 1975, "Fundamentals of Metal Machining and Machine Tools, International Student Edition”, McGraw-Hill, Tokyo, Japan.

[13] Rochim T. Teori dan teknologi permesinan, HEDS, (1993) 
[14] Mike L.P. Groover, Fundamentals of ModernManufacturing,Prencice Hall, Upper Saddle River, New Jersey 07458, 1996.

[15] Apri Nuryanto \& Sutopo, Pengaruh variasi kecepatan potong, feeding dan Kedalaman potong terhadap umur pahat hss yang dilapis aln-tin-aln, (2006).

[16] Manage, D.P. (1998). Structural and Optical Characterization of Hydrogen Amorphous Carbon Thin Films. University of Toronto: Ph.D Thesis.

[17] Dischler B, Wild C, (Eds.) (1998), Low-Pressure Synthetic Diamond. Manufacturing and Applications. Springer-Verlag, Berlin.

[18] ISO 3685, "Tool-life testing with single-point turning tools",1993.

[19] Kalpakjian, S.,"Manufacturing processes for engineering materials", Wesley Publishing Company, USA, (2003).

[20] Castrol ,Aluminium Machining, Your Industry, 2004.

[21] www.matweb.com. Materials Information. 20102.

[22] Schulz H., Moriwaki T. High - speed machining, Ann. of the CIRP, (1992).

[23] Sandvik Coromant, General Catalogue, (2012). 